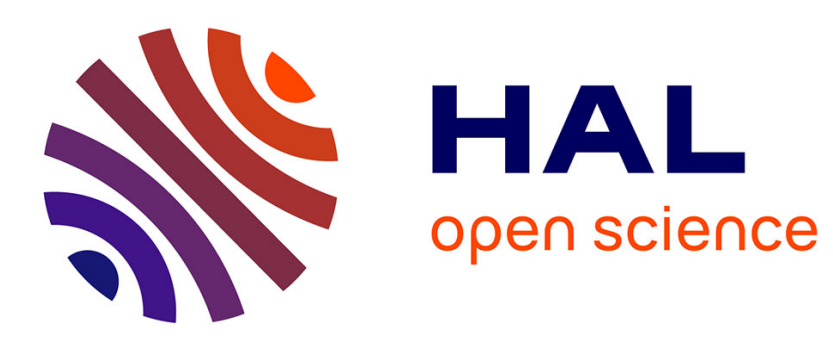

\title{
Estimating the local paleo-fluid flow velocity: New textural method and application to metasomatism
}

Stanislas Sizaret, Yannick Branquet, Eric Gloaguen, Alain Chauvet, Luc Barbanson, Laurent Arbaret, Yan Chen

\section{To cite this version:}

Stanislas Sizaret, Yannick Branquet, Eric Gloaguen, Alain Chauvet, Luc Barbanson, et al.. Estimating the local paleo-fluid flow velocity: New textural method and application to metasomatism. Earth and Planetary Science Letters, 2009, 280 (1-4), pp.71-82. 10.1016/j.epsl.2009.01.013 . insu-00352307

\section{HAL Id: insu-00352307 https://hal-insu.archives-ouvertes.fr/insu-00352307}

Submitted on 12 Jan 2009

HAL is a multi-disciplinary open access archive for the deposit and dissemination of scientific research documents, whether they are published or not. The documents may come from teaching and research institutions in France or abroad, or from public or private research centers.
L'archive ouverte pluridisciplinaire HAL, est destinée au dépôt et à la diffusion de documents scientifiques de niveau recherche, publiés ou non, émanant des établissements d'enseignement et de recherche français ou étrangers, des laboratoires publics ou privés. 


\section{Estimating the local paleo-fluid flow velocity:}

\section{New textural method and application to metasomatism}

Stanislas Sizaret ${ }^{\mathrm{a}^{*}}$, Yannick Branquet ${ }^{\mathrm{a}}$, Eric Gloaguen ${ }^{\mathrm{b}}$, Alain Chauvet $^{\mathrm{c}}$, Luc Barbanson $^{\mathrm{a}}$, Laurent Arbaret ${ }^{\mathrm{a}}$, Yan Chen ${ }^{\mathrm{a}}$.

${ }^{a}$ Université d'Orléans, Université François Rabelais - Tours, CNRS/INSU

Institut des Sciences de la Terre d'Orléans - UMR 6113

Campus Géosciences

1A, rue de la Férollerie

41071 Orléans cedex 2

France

${ }^{\text {b }}$ Bureau de Recherches Géologiques et Minières, 3 avenue Claude-Guillemin - BP 36009 45060 Orléans Cedex 2, France

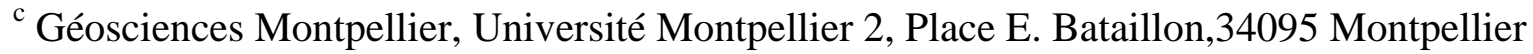
cedex 5, France

${ }^{*}$ Corresponding author.

E-mail address: stanislas.sizaret@univ-orleans.fr

Tél. : (33) 0238255396

Fax. : (33) 0238636488

\section{Abstract}


Crystal growth driven by a flowing solution is modeled for a flow with low Reynolds number using a computational dynamic software. Considering equivalent crystallographic faces, the chemical flux is calculated along upstream and downstream faces. Upstream flux is higher compared to downstream and leads to a symmetry breakdown of the crystal shape and develops mirror symmetry parallel to the flow velocity. Moreover the ratio of these two fluxes (upstream / downstream) gives a quantitative relation between the relative crystal growth rate and the flow velocity. Thus, using an inverse method, the flow direction and velocity can be deduced by the study of the variation of the growth band thicknesses of equivalent crystallographic faces.

This new method was applied to the formation of metasomatic tourmalinite associated with a leucogranite sill. The approach is complemented by a study of the chemistry of the tourmaline. In the studied case, the application of the new method gives the high fluid velocities in pores $\left(10^{-3}-10^{-4} \mathrm{~m} / \mathrm{s}\right)$ during metasomatism. Equivalent Darcy velocities are estimated and discussed accounting for the major role played by the regional deformation. Finally, a two-stage tectono-hydrodynamic model is proposed for the metsomatism. The first stage is genetically linked to the sill injection, and the second is characterized by a wider event with hydrothermal flow passing along the leucogranite sills.

Keywords: hydrothermal activity, grain scale flow velocity, flow direction, crystal growth, tourmaline, metasomatism. 


\section{Introduction}

The description of paleo-fluid flow is fundamental for understanding geological processes such as ore deposition (Barnes, 1997), rock deformation (Gratier and Gueydan, 2007), and metamorphism (Ferry et al., 2002). The predominant direction of flow is commonly inferred from transport theory applied to chemical alteration, stable isotope ratios, progress of mineral reactions and trace element data (Ferry et al., 2002; Cartwright and Buick 1996). The review of Ferry et al. (2002) for fluid flow during contact metamorphism shows that direction do not obey to simple generalizations law because the major control is the permeability structure, either inherited from initial layering, or resulting from the coeval deformation (Ferry et al., 1998; Rossetti et al., 2007). Mass balance could give information about time-integrated fluid fluxes. Wing and Ferry (2007) recently present a study where the pattern of the isotopic signal and whole-rock $\mathrm{CO}_{2}$ concentration is interpreted as geological record of paleo-flow. Their results point to significant time-integrated fluxes $\left(5000-300 \mathrm{~mol} / \mathrm{cm}^{2}\right)$ consistent with the order of magnitude published in previous studies (Ferry, 1994a). Thermal and hydrological numerical models constitute another approach to constrain the direction and amount of fluid flow (Norton and Knight, 1977; Hanson et al., 1993; Gerdes et al., 1998; Cui et al., 2001; Oliver et al., 2006). In some case, good agreement is found between predictions from numerical models and studies based on mineralogical and stable isotope data (e.g. Hanson et al., 1993 and Ferry et al., 1998).

However, even though in some spectacular cases, mineral reaction fronts provide information at the meter scale (Ferry et al., 1998), the direction, velocity and pattern of fluid flow are generally deduced from space- and time-integrated data, over large kilometer scales in hydrothermal systems. At outcrop scales (typically one meter), direct measurements of orientation and velocity of fluid flow are usually not assessed by the methods mentioned 
above. Moreover, suitable mineral assemblages (e.g., siliceous carbonate or limestone protoliths) and/or isotopic ratios are required, which is not the general case.

This paper presents a method to estimate quantitatively, at the crystal scale, flow velocity from the measurement of the variation of the crystal growth band thicknesses. Based on a crystal scale fluid flow analysis, we present a numerical model: considering crystallographic equivalent crystal faces, we establish the dependence between flow velocity and the ratio of the growth band thickness of crystal faces (i.e. short time-integrated growth rate) in the upstream and downstream positions. In the second part, applying the inverse method, we estimate the fluid flow velocity (scalar and vector) involved in the formation of tourmalinite during metasomatism.

\section{Multiscale fluid flow analysis}

The transport equations governing the chemical fluxes can be used to define global or local fluxes:

$$
\frac{\partial c}{\partial t}=D \nabla^{2} c-V \cdot \nabla c
$$

where, $c$ is concentration (mol/l), $t$ the time (s), $D$ the diffusion coefficient $\left(\approx 10^{-9} \mathrm{~m}^{2} / \mathrm{s}\right)$ and $V$ the flow velocity $(\mathrm{m} / \mathrm{s})$.

From this expression it is possible to separate terms characterizing two physical processes: i) diffusion along a concentration gradient and ii) advection due to fluid flow. This transport equation is valid at every scale. The flow velocity has different physical meaning according to the considered scale. A macroscopic formulation of the velocity is given by the Darcy law (i.e. Darcy velocity $V_{D}=V_{\text {Pore }} \theta, V_{\text {Pore }}$ is the mean microscopic flow in the pore and $\theta$ is the porosity). At grain scales (local velocity), the general Navier Stokes equation is used and can be simplified for high values of local Reynolds number (Sizaret et al., 2006a). 
A megascopic flow description is generally chosen because models are used to evaluate bulk flux processes where a porous-medium approximation seems reasonable when averaged over time and volume (see section "applicability of the Darcy law" in Manning and Ingebritsen, 1999). At this scale the average rock hydraulic behavior is well described using the Darcy law:

$$
\vec{V}_{D}=-\left[\frac{k}{\mu}\right] . \vec{\nabla} P
$$

$\vec{V}_{D}$ is the volumetric flux $\left(\mathrm{m}^{3} / \mathrm{m}^{2} \mathrm{~s}=\mathrm{m} / \mathrm{s}\right)$ also called the Darcy velocity, and the actual mean local flow velocity in porosity Vpore is much greater. $k$ is the intrinsic permeability $\left(\mathrm{m}^{2}\right), \mu$ is the dynamic viscosity (Pa.s) about $10^{-4}$ Pa.s for $\mathrm{H}_{2} \mathrm{O}-\mathrm{CO}_{2}$ fluids in most metamorphic systems (Walther and Orville, 1982), and $P$ is the fluid pressure (Pa). The pressure gradient depends on driving forces such as buoyancy, topography and pressuredriven fluid expulsion caused by either transient changes of porosity or fluid production (i.e., magmatic and/or metamorphic). The permeability is related to the connected porosity that is low $(<0.1 \%)$ for metamorphic rocks. At middle to lower crust conditions, adsorbed films of fluid exists along grains boundaries, and fluid migration is controlled by surface energy and diffusion (Carlson 1989; Carlson 1991). As a result, at this scale, the flow is not Darcian. In such an environment, enhanced permeability, and hence applicability of the Darcy law, is related to the opening of connected free space during deformation (Ferry 1994b; Brenan, 1991). Thus, for sufficiently long time and volumes, deformed crystalline rocks can be reasonably considered as a porous medium equivalent. In this case of macroscopic Darcian flow, in the upper crust, Manning and Ingebritsen (1999) show that for permeabilities $>10^{-16}$ $\mathrm{m}^{2}$, heat and solute advection dominates over heat conduction and molecular diffusion respectively. Ferry and Dipple (1991), on the other hand, argue that heat transport during 
most instances of contact and regional metamorphism is by conduction rather than by advection.

At the grain scale, fluid flow is not Darcian and flow velocity is governed by Continuity and the Navier Stokes equation, which for uncompressible Newtonian fluid is

$$
\left\{\begin{array}{c}
\vec{\nabla} \cdot \overrightarrow{\mathrm{V}}_{\mathrm{N}-\mathrm{S}}=0 \\
\frac{\delta \overrightarrow{\mathrm{V}}_{\mathrm{N}-\mathrm{S}}}{\delta \mathrm{t}}+\left(\overrightarrow{\mathrm{V}}_{\mathrm{N}-\mathrm{S}} \cdot \vec{\nabla}\right) \overrightarrow{\mathrm{V}}_{\mathrm{N}-\mathrm{S}}=-\frac{1}{\rho} \vec{\nabla} \mathrm{P}+\mathrm{u} \nabla^{2} \overrightarrow{\mathrm{V}}_{\mathrm{N}-\mathrm{S}}+\overrightarrow{\mathrm{f}}
\end{array}\right.
$$

With $\vec{V}_{N-S}$ the fluid velocity $(\mathrm{m} / \mathrm{s}), \rho$ the density $\left(\mathrm{kg} / \mathrm{m}^{3}\right), v$ the kinematic viscosity $\left(\mathrm{m}^{2} / \mathrm{s}\right)$ $(v=\mu / \rho)$, and $\vec{f}$ the volume force (N/kg). The analytical solution of (3) does not exist and is one of the Millennium Prize Problems. However analytical approximate solutions exist depending on the Reynolds number value and the geometry of the fluid solid interface (edge, cylindrical, spherical). Taking the transport equation at the grain scale, the limit between solute diffusion and advection is given by the diffusion coefficient: $10^{-9} \mathrm{~m}^{2} \mathrm{~s}^{-1}$ at $25^{\circ} \mathrm{C}$ to $10^{-8}$ $\mathrm{m}^{2} \mathrm{~s}^{-1}$ at $500^{\circ} \mathrm{C}$ (Ildefonse and Gabis, 1976; Labotka, 1991).

The influence of flow on crystal shape has been investigated for the last 30 years. Garside et al. (1975) show the increase of the bulk crystal growth with super saturation and the square root of the flow velocity. Theirs experiments show that the variation of the bulk growth rate increase at low velocity and high supersaturation. Prieto et al. (1996) considered three orientations: normal facing to the flow, parallel to the flow and in downstream position or 'in the shade'. In the two previous cases, the authors invoked the classical hydrodynamic boundary layer theory to account for mass transfer through the 'concentration boundary layer'. In the 'shade' position, experiments show lower growth rate: in these experiments the crystal growth is perturbed by eddy flow difficult to model from the hydrodynamic point of view.

Control of crystal growth rate could be largely described by the combination of two processes: i) chemical volume diffusion within the boundary layer occurring along the crystal 
faces; and ii) surface processes (Gilmer et al., 1971). If volume diffusion is the slower process, crystal growing in flowing solution records variable growth band thickness related to a different growth rate for crystallographic equivalent faces that are determined by the chemical flux feeding given by the transport equation (1).

Sizaret et al. (2006a) solved the Navier Stokes equation for high Reynolds numbers in a semi-infinite wedge to model the growth of a single crystal in a moving fluid of constant concentration. A main result is a quantitative relation between flow direction and crystal elongation. A secondary result is that for semi-infinite geometry and high local Reynolds number, i.e., $\operatorname{Re}_{x}=x . V(x) / v>>1$, ( $x$ is the position considered along the crystal face, $V(x)$ is the local flow velocity, $v$ is kinematic viscosity) the crystal growth rate varies with the square root of the flow velocity. Thus for high local Reynolds number, the ratio between the growth rate of the different faces is not velocity dependent. Further, we evaluate whether this result is valid for closed geometry and low Reynolds number. Moreover, the model developed in Sizaret et al. (2006a) considers a solution without concentration gradient. The existence of such gradient is dependant on the distance between the considered growthing crystal and his nearest neighbors, because, during growth, a "chemical affinity gradient will arise and persist” forming “depleted zones” that enlarge and coalesce (Carlson 1989, Carlson 1991, Skelton 1997). Carlson (1989) established at each instant a relation of proportionality between the depleted zone and the crystal radius: $R_{i}^{d p l^{*}}=\beta R_{i} . \beta$ is the dimensionless proportionality constant relating the radius of each crystal $R_{i}$ to the radius of the depleted zone $R_{i}^{d p l^{*}}$. Carlson (1991) uses this relation to model the growth of porphyroblasts by intergranular diffusion. Skelton (1997) uses the relation to model garnet growth during metasomtism. For pervasive flow and channeled flow the value of $\beta$ is about 2 (metasomatism occurrence in the upper green schist facies, Skelton 1997). In this paper we will use the chemical diffusion thickness (Sizaret et al. 2006a) to estimate the area where the concentration gradient is high and the 
obtained values will be compared to the length of the depleted zone estimated in the Skelton (1997) model.

\section{Modeling}

In order to analyze the influence of flow on crystal growth, the equation (1) is solved for a single crystal with an idealized geometry. The local fluid velocity $V_{N-S}$ is computed from the Continuity and Navier Stokes equation (3) for variable upstream flow velocity (Sizaret et al. 2004). For each simulation the chemical diffusion thickness (Sizaret et al. 2006b) is calculated to estimate the "depleted zones" defining the limit in which the crystal grew independently of this nearest neighbors. The results will be exploited by comparing the chemical fluxes of differently orientated faces for varying flow velocities.

\subsection{Equation, parameters and boundary conditions}

We consider a crystal immersed in a flowing solution with a constant upstream velocity $V_{\infty}$ and concentration $C_{\infty}$. The crystal geometry is simplified as a 2-D description with a regular polygonal section (Fig. 1). At the crystal surface, the fluid velocity is zero due to viscosity. Rapid incorporation of solute in the crystal keeps the wall concentration $C_{w}$ constant close to the saturation level depending on the crystal solubility. Such conditions describe well the case of crystal growth limited by low saturation of one element. $C_{w}$ is similar for all faces, i.e., the properties of the crystal section is isotropic. The concentration profile from the crystal wall $C_{w}$ to infinity $C_{\infty}$ is used to deduce the chemical gradient and the chemical flux along the crystal face. This gradient is driven by the transport equation depending on the diffusion coefficient and the local flow velocity around the crystal. The velocity is given by the Navier Stokes equation. 
In order to fixe a straight-out velocity, the pressure is fixed constant equal to zero. The local chemical flux along crystal face is calculated for variable upstream flow $V_{\infty}$. To give general results independent of $C_{\infty}$ and $C_{w}$, dimensionless concentration is used and defined as:

$$
\chi(x, y)=\frac{C_{w}-C(x, y)}{C_{w}-C_{\infty}}
$$

$\chi(x, y)$ varying from $\chi_{\infty}=1$ far away from the crystal in upstream position to $\chi_{w}=0$ along the crystal wall (Fig. 1A). To evaluate the influence of the depleted zone the local diffusion thickness $\Delta\left(x^{\prime}\right)$ is calculated using concentration gradient along the crystal wall (Sizaret et al. $\left.2006^{\mathrm{a}}\right)$.

$$
\Delta\left(x^{\prime}\right)=\frac{1}{\left.\frac{\delta \chi\left(x^{\prime}, y^{\prime}\right)}{\delta y^{\prime}}\right|_{y=0}}
$$

With $x$ ' being the coordinate along the crystal face and $y$ ' the perpendicular coordinate.

The coupled Navier Stokes and transport equations are solved using the Femlab3.1i finite difference code. This multi-physics software runs the finite element analysis together with adaptive meshing and error control using a variety of numerical solvers. In this work the nonlinear incompressible Navier Stokes and transport equation are solved for steady state using the damped Newton method with criteria of convergence fixed to $10^{-12}$. The calculation is applied assuming laminar flow and an ideal crystal shape modeled by hexagon with edges of $50 \mu \mathrm{m}$ length. The calculation is performed for water at $25^{\circ} \mathrm{C}, 1 \mathrm{Mpa}$ and at $350^{\circ} \mathrm{C}, 185$ Mpa, implying diffusivity varying between $10^{-9}$ and $20.10^{-9} \mathrm{~m}^{2} / \mathrm{s}$, and kinematic viscosity between $10^{-6}$ and $1.3 \cdot 10^{-7} \mathrm{~m}^{2} / \mathrm{s}$ (Fig. 1B). 


\subsection{Results}

The results give the concentration decreases close to the crystal (Fig. 1B), the flux of dimensionless mass (i.e.; $\left.D \frac{\delta \chi\left(x^{\prime}, y^{\prime}\right)}{\delta y^{\prime}}\right|_{y^{\prime}=0}$ ) (Fig. 1C) and the diffusion thickness could be calculated along crystal wall (Fig. 1D).

Close to the crystal edges, the chemical flux is high because advection blows the concentration profile and increases the concentration gradient. Therefore, in the edge area, the flux is relatively high and the surface processes are slower than the volume diffusion. If diffusion is still the slowest process the growth should be localized on the edges giving dendritic shapes. In other case, the crystal growth is limited by surface processes in this area and the crystal growth rate computed is locally over estimated. Therefore, the real mean crystal growth rate of a face is lower than the average of the computed wall fluxes and higher than the minimum of the computed curve.

The diffusion thickness is inversely proportioned to the flux (5), based on the flux profiles it is easy to show that the diffusion thickness is maximum at the centre of the crystal face (Fig. 1C). In figure 1D the concentration profile illustrate that gradient concentration is strong close to the crystal wall. Far of the crystal on upstream position the gradient begins sharply and far in downstream position this gradient vanishes smoothly. Therefore, the maximum diffusion thickness $\Delta$ calculated is shorter on upstream than along downstream face.

For velocities $V_{\infty}$ varying from $10^{-6}$ to $10^{-2} \mathrm{~m} / \mathrm{s}$ the chemical wall flux (i.e., crystal growth rate) and the diffusion thickness is calculated for each face. For $V_{\infty}>10^{-2} \mathrm{~m} / \mathrm{s}$ the calculation diverges because the flow reaches a turbulent regime. The minimum and average fluxes calculated on the upstream face are divided by the minimum and average fluxes of the downstream face, respectively. The flux ratio $\mathrm{R}$ is plotted against the velocity (Fig. 2A). For all curves, $\mathrm{R}$ increases with the flow velocity and in the limit $V_{\infty} \rightarrow 0 \mathrm{R}=1$, because if the 
fluid is immobile, the concentration gradient is the same in all directions. The difference between the minimum and average flux ratios is important for high flow velocity at low temperature. At $25^{\circ} \mathrm{C}$ and up to $10^{-4} \mathrm{~m} / \mathrm{s}$, the estimation of velocity using the average and minimum curves show a difference of one order of magnitude (Fig. 2A). The calculation of the diffusion thickness is reported in the figure $2 \mathrm{~B}$ and the obtained value vary from $50 \mu \mathrm{m}$ to $400 \mu \mathrm{m}$. As discussed before the upstream face has a lower diffusion thickness than the downstream face, in addition the diffusion thickness increase with temperature and decrease with the flow velocity. Skelton (1997) model allows estimating the radius of the depleted zone close to the crystal radius. In our model with crystal radius about $50 \mu \mathrm{m}$ at $350^{\circ} \mathrm{C}$ the diffusion thickness is more than $150 \mu \mathrm{m}$ for velocity $\left(<10^{-4} \mathrm{~m} / \mathrm{s}\right)$. A possible explanation for this difference is that the diffusion thickness calculates in steady state at low velocity is not effective because the crystal is growing faster than time necessary to reach the steady state. In such case the depleted zone is driven by the crystal size. For velocities around $10^{-3} \mathrm{~m} / \mathrm{s}$ the model given by Skelton (1997) and our are consistent with diffusion thickness about $50 \mu \mathrm{m}$.

The major result of this modeling is that the flux ratio curves show a quantitative link between the crystal growth rate and the flow velocity. It demonstrates that it is possible to estimate flow direction and velocity by measuring growth bands thicknesses. However this model is based on fluid without gradient of concentration. This hypothesis is well respected if during growth the neighbors do not create strong local gradient of concentration. This could be checked by estimating the distance between crystals that should be longer than the calculated diffusion thickness. This estimation depends on flow velocity and temperature.

\section{Application to tourmalinite}

In the following part we apply the inverse method to estimate the local flow that occurred during metasomatism that produced a natural occurrence of tourmalinite. 


\subsection{Geology}

Tourmalinites have been sampled within the Galicia-tras-os-Montes orogenic segment of the Spanish Hercynian belt (Fig. 3A). Between 325 and 300 Ma, this area underwent magmatism associated with a late orogenic event leading to northward-directed horizontal stretching (Gloaguen et al., 2004; Gloaguen, 2006; Gloaguen et al., 2008;). In relation to emplacement of specific pluton (the “G2”granite generation, see Gloaguen et al., 2003), the hosting micashists were affected by a strong and massive tourmalinization.

Significant volumes of tourmalinites are exposed in the vicinity of the Beariz pluton (Fig. 3B). This pluton is a composite magmatic complex made of older G1 porphyric granite intruded by a G2 leucogranite and associated aplite and pegmatite dykes and sills. The G2 magmatic suite of Beariz is composed of albite-rich leucogranite, characterized by a muscovite-tourmaline-garnet assemblage. High contents of Sn (up to 1005 ppm), Ta, Nb and F (up to $0.11 \%$ weight) make this leucogranite an unusual type (Gloaguen, 2006). In some place, it has been mined for a disseminated magmatic Nb-Ta-Sn mineralization (colombotantalite and cassiterite being the main minerals). Related to G2 leucogranite emplacement, alteration halos of tourmalinite developed within mica schists at their contact with G2 dykes and sills. Finally, as the magmatic-hydrothermal transition progressed, thick hydrothermal quartz veins developed around the Beariz pluton (Fig 3B). These veins bear an important Sn-W mineralization, mined in the middle of the 20th century.

It is noteworthy that the G2 leucogranite, the tourmalinite halos and the Sn-W-bearing quartz veins, were emplaced and formed during a continuous E-W shortening (N-S trending upright folds and axial vertical cleavage) and associated N-S stretching, leading to an intense E-W fracturing affecting the Beariz pluton area (Gloaguen, 2006; Gloaguen et al., 2003). 


\subsection{Outcrop}

Two sites have been sampled around the Beariz pluton (Fig. 3B). The Mina Soriana outcrop (Fig. 4A, D) exposes a horizontal sill of G2 leucogranite injected into mica schist. The leucogranite sills underwent hydrothermal alteration. Tourmalinite halos, approximately $50 \mathrm{~cm}$ in maximum thickness, are developed along the lower and upper sill wallrocks. The foliation planes of mica schist display a N 165 E 20 NE stretching lineation marked by quartz rods and mineral alignments. Two types of steeply dipping veins are observed (Fig 4A). Both types, sub-normal to the stretching lineation, are compatible with a broad N-S horizontal extension. As a result, the sills and tourmalinite are boudined broadly along a N-S direction. The first type of vein, 0.1-10 centimeters thick, crosscuts the sill-tourmalinite halos where they are preferentially localized (Fig. 4A, B, D). They are filled with quartz, tourmaline, and accessory muscovite. Within veins, tourmalines are found along wallrocks with long axis parallel to the opening direction (Fig. 4C). This argues for a formation of veins as sealed extensional fractures. Quartz fills the center of the vein. A second type, devoid of tourmaline, is a meter-thick Sn-W-sulfides- bearing quartz vein which was mined at Mina Soriana. Crosscutting relationships show that this vein was the last event on this outcrop.

The Marcofán outcrop exposes a subvertical N170E-trending G2 pegmatite sill that cuts across the foliation of micaschists (Fig 5A, B). Tourmalinite halos, $40 \mathrm{~cm}$ in maximum thickness, are developed within mica schists on both sill wallrocks. The pegmatite displays a symmetric zoning with quartz-muscovite at the centre and a quartz-feldspar-muscovite assemblage along the borders. The pegmatite borders and tourmalinites are crosscut by vertical N90E trending quartz-muscovite extensional veins directly "connected” to the centre part of the pegmatite (Fig. 5B). This suggests that tourmalinization occurred during the first stage of the pegmatite emplacement, i.e., coeval with the crystallization of the quartz- 
feldspar-muscovite border assemblage. Finally, the outcrop exposes structures highly compatible with the broad N-S extension marked by N-S elongated quartz rods.

Both outcrops present small cleavage-parallel quartz veinlets parallel to sill wallrocks (Fig. 4D and 5B).

For both outcrops, the transition between tourmalinite halos and non-altered micaschists is gradual.

\subsection{Texture, growth banding and chemistry of tourmalinite}

For both outcrops, tourmalinite is mainly composed of tourmaline, quartz and muscovite (Figs. 4E, F and 5C, D). At some places, muscovite mimics the ghost cleavage of the host mica schist. However, the major fabric of the tourmalinite is the strict N-S alignments of the tourmaline long axis. Indeed, for both outcrops, vertical W-E thin sections present exclusively trigonal tourmaline basal section normal to the c axis (Figs. 4F and 5D). In sections parallel to the c-axis, tourmaline crystals appear to be truncated by vertical E-W-trending healed cracks and/or quartz-filled veinlets (Figs. 4E and 5C). At Mina Soriana, E-W-trending truncation planes or veinlets are also observed affecting tourmalines within quartz-tourmaline veins. This microscopic truncation is compatible with the boudinage observed at larger scale (cf. supra).

Within tourmalinite, pseudo-hexagonal basal sections show spectacular zoning and growth banding of tourmalines (Figs. 4F and 5D). Growth bands and cores have been optically distinguished, and electron microprobe analysis was performed along transects. To compare, we analyzed also: i) zoned tourmalines from tourmaline-quartz veins crosscutting the tourmalinite halos; ii) disseminated tourmaline within mica schist up to 1 meter from tourmalinites; iii) tourmalines in G2 sills wallrocks; and iv) tourmalines disseminated within the G2 Beariz leucogranite (Fig. 6). 
With the exception of some tourmaline cores from quartz-tourmaline veins, all tourmaline types are from the alkaline group. Tourmalines from mica schists and cores from tourmalinites have compositions intermediate between dravite and schorl (Fig. 6A). Evolution from dravite to schorl traces the transition from metamorphic to magmatic chemical controls (Fig. 6A). Because the tourmaline cores from tourmalinites are close to the composition of tourmaline from mica schist, we think that initiation of tourmaline crystallization in tourmalinite is controlled by the chemistry of the hosting mica schist. However, tourmaline cores from quartz-tourmaline veins strongly differ from cores of tourmalinites (Fig. 6B). One explanation may be that, due to incipient tourmalinization, chemical buffering of mica schist was weaker leading to a stronger magmatic-hydrothermal signature of the fluids.

Finally, tourmaline growth bands from both quartz-tourmaline veins and tourmalinite have the same Li-Al depleted composition (Fig. 6A). This suggests that, during the late tourmalinization stage, tourmalinites and veins were infiltrated by the same hydrothermal fluid partially buffered by the chemistry of host mica schist.

\subsection{P-T conditions of tourmalinite formation}

P-T conditions of tourmalinization have been estimated from the application of geothermometers, coupled with fluid inclusion studies. The muscovite-phengite geothermometer (Monier and Robert, 1986) applied to the muscovites from tourmalinites at Mina Soriana gives temperature below $400^{\circ} \mathrm{C}$. To constrain the pressure of tourmalinite formation, we used fluid inclusion data obtained on $\mathrm{Sn}-\mathrm{W}$ bearing quartz veins which postdates the major phase of tourmalinization (Gloaguen, 2006). The resulting minimum pressure for the quartz vein formation is $185 \mathrm{Mpa}$, i.e around $7 \mathrm{~km}$ which therefore represents, in our case, the minimum pressure for tourmaline crystallization. 


\subsection{Measurements and flow velocity estimations during tourmalinization}

In this part we apply the model developed previously to characterize the metasomatic flow involved in the formation of tourmalinite. To estimate the fluid velocity and direction we use the inverse method: statistical measures of the growth band thickness in tourmaline are inverted to estimate flux ratio along crystal face, and then, a flow velocity is deduced using the curve of the figure $2 \mathrm{~A}$.

To obtain good measurements, the studied sections have to be chosen carefully. Any face in contact with others was eliminated as the proximity of the other crystal perturbs the local chemical flux. When the section is chosen, it is necessary to find the position of the initial nuclei, it has been approximately located close to the centre of the tourmaline core (Fig. 7A).

Tourmaline is uni-axial, and the (0001) section is isotropic with a trigonal symmetry. To compare growth band thicknesses in one crystal section, measurements were performed in three equivalent directions separated by $120^{\circ}$ (Fig. 7A). Due to trigonal symmetry, these three directions have the same crystallographic properties and the different growth band thicknesses quantify the different chemical fluxes on a small integrated time. However, the crystallographic directions chosen in the different crystals are not strictly equivalent. To compare them the measures were normalized to the mean value of the three measurements (Fig. 7B). For each crystal measured, three normalized thicknesses are obtained $d_{\max }, d_{\text {int }}$, $d_{\text {min }}<1$ with their corresponding direction. The average $d_{\text {int }}$ direction is normal to flow trend whereas the average $\mathrm{d}_{\min }$ direction indicates directly the velocity direction. The chemical flux ratio is estimated by the $d_{\max } / d_{\min }$ ratio. Finally, the minimal average half distance between cores has been evaluated at $54 \mu \mathrm{m}$ for the four thin sections analysed.

Tourmalinite formed at both outcrops were studied following this method. Four thin sections has been sampled with similar orientation for each studied sites. Each sections were analyzed with 102 growth band thicknesses measurements on 34 tourmaline basal sections. 
To study the relation between the magmatic intrusion and the fluid circulation, in both cases the measurements were performed on both side of the intrusion. The measurements on the Mina Soriana outcrop were performed above (Figs. 8A, B) and below the sill (Figs. 8C, D). To control the consistency of the measurements, the average direction of $d_{\max }$ is compared to $d_{\text {min }}$. Their mean directions are calculated and suggest an eastward flow direction convergent toward the sill.

The tourmalinite from the Marcofán outcrop were analyzed in the same way (Fig. 9). The results suggest the flow circulation parallel to the schistosity with a component converging toward the pegmatite.

The average ratio $d_{\max } / d_{\min }$ presented in figure 8 and 9 ranges from 1.5 to 2.2 suggesting flow velocity varying from $10^{-4}$ to $10^{-3} \mathrm{~ms}^{-1}$ in the plane of measurements (Fig. 2A). Using the result obtains on flow velocity the diffusion thickness could be estimated between 65 and 110 $\mu \mathrm{m}$ (Fig. 2B).

For low velocities about $3.10^{-4} \mathrm{~m} / \mathrm{s}$ (Fig. 9C, D), the diffusion thickness is about $110 \mu \mathrm{m}$ suggesting that next neighbors influenced the crystal growth. Relatively to the average half distance measured between cores $(54 \mu \mathrm{m})$, the condition of application of the method is not well-satisfied. Nevertheless, the flow direction deduced from $d_{\max }$ and $d_{\min }$ are coherent with a large $\alpha_{95}$ incertitude $\left(135^{\circ}\right)$.

For higher velocities around $10^{-3} \mathrm{~m} / \mathrm{s}$,(Fig. 8 and 9A, B), the diffusion thickness is about $65 \mu \mathrm{m}$. Then, the conditions are satisfied at the beginning of the crystal growth, but not at the end of the crystallization.

In general, the results on the direction of $d_{\min }$ and $d_{\max }$ are coherent suggesting that the signal of the flow is relatively well preserved.

\section{Discussion}

The study of the tourmaline growth band has two mains results: 
i) The grain scale flow velocities are relatively high.

ii) During band growth (i.e. late stage of tourmalinization), the hydrothermal flow converges toward the magmatic sills at relative low angle $\left(<45^{\circ}\right)$.

\subsection{Velocity analysis and the role of deformation}

Darcy's law gives the average flow in a rock, but flow is not homogeneous as it is channellized in large scale open structures. In megascopic modeling, stream line and pressure gradient are generally very regular. At the grain scale, our measurements show widely variable flow directions (Figs. 8 and 9). This could be due to the tortuous geometry of the solid-liquid interface in a complex porosity but also to influence of the neighbours at the end of the crystal growth.. In this study, the average of the grain scale measured directions could be used only to estimate a broad general trend. The mean direction is assimilated to the macroscopic flow direction related to pressure gradient that could be controlled by contact metamorphism and/or fracturing (e.g. pumping effect).

Darcy velocities, from time-integrated flux based on mineral reactions and stable isotopes studies range from $10^{-9} \mathrm{~m} / \mathrm{s}$ to $10^{-11} \mathrm{~m} / \mathrm{s}$ for contact metamorphism (Ferry et al., 2002). For active regional metamorphism, a Darcy velocity of $10^{-11} \mathrm{~m} / \mathrm{s}$ is considered to be an average value (Ingebritsen and Manning 1999). Hydrothermal numerical models of contact or regional metamorphism, predict Darcy velocities ranging from $10^{-8} \mathrm{~m} / \mathrm{s}$ to $10^{-11} \mathrm{~m} / \mathrm{s}$ (Oliver et al., 2006; Gerdes et al., 1998; Cook et al., 1997). In this work, the calculated velocity at grain scale is much higher, about $10^{-3}$ to $10^{-4} \mathrm{~m} / \mathrm{s}$. These are equivalent to $V_{\text {Pore }}$, and approximating host schists as a porous equivalent media with an averaged $0.1 \%$ porosity, Darcy velocities during tourmalinization would range from $10^{-6}$ to $10^{-7} \mathrm{~m} / \mathrm{s}$, not so higher than published values. Moreover hydrodynamic models of fluid flow usually assume continuous flow, and field estimates of $V_{D}$ divide a time integrated fluid flux by an estimation of the total duration of the flow event. Those high velocities imply that the solute transport is achieved by solute 
advection rather than diffusion and it seems reasonable to consider moving fluids as discontinuous hydrothermal discharge within connected porosity.

Our results are matter of further discussion for two reasons: i) in our field examples, the potential horizontal component of the velocity vector cannot be assessed with this textural method. Thus, deduced Darcy velocities from our measurements deal only with the vertical components of fluid flow and are underestimated; ii) during hydrothermal replacement of host schists, the transient connected porosity might be higher than $0.1 \%$. Indeed, it is well established that fluid pressure and deformation interact to control fluid flow within rocks (see, Gratier and Gueydan, 2007 and references herein). The observed fracturing within the tourmalinite halos at a range of spatial scales strongly suggests hydrofracturing at an hydrothermal reaction front. Because differential stress is not zero, at all scales, a regular set of vertical E-W-directed extension fractures (i.e., mode 1 fractures) formed. Moreover, effective stresses may decrease below the strength of anisotropies such as cleavage of host mica schist. As a result, at all scales, cleavage-parallel fractures may open, coeval with extension fractures (Fig. 5B). Consequently, cleavage-parallel fractures and E-W -trending vertical extension fractures, were likely the major fluid channels during a local and regional N-S stretching. Finally, considering the likelihood of a transient connected porosity higher than $0.1 \%$ during tourmalinization and deformation, we think that massive metasomatism implies an equivalent Darcy velocity higher than those measured in contact and regional metamorphism.

\subsection{Relation between flow direction, sill and large scale hydrothermal system}

The tourmaline occurrences are strictly associated with the magmatic intrusion. In both studied outcrops, average flow directions converge toward the sill suggesting the existence of a hydrothermal flow "channeled” or "pumped” along the fracture network (cleavage parallel and E-W trending vertical fractures). Such observation suggests that hydrothermal flow 
occurring during the tourmaline band growing is not strictly related to sill injection. This is consistent with the observed alteration of the sill (Figs 8 and 9) and confirmed by the homogenous composition of the growth bands for tourmaline from mica schists, tourmalinite and quartz veins (Fig. 7B). Hence, at the pluton scale, a homogenous hydrothermal fluid, buffered by mica schist, flowed during last stage of tourmalinization.

\subsection{Proposed tectono-hydrodynamic model}

The analysis of the relationships between sill, tourmaline occurrences, and hydrodynamics, suggests a two stage model (Fig. 10)

The first stage (Fig. 10A) is clearly identified by the composition of the tourmaline cores involving a genetic link with the leucogranite sills (boron source) and buffered by the mica schist for $\mathrm{Fe}, \mathrm{Al}$ and $\mathrm{Mg}$ elements (Fig. 6B). This relation is consistent with the association between tourmaline and magmatic bodies. Crystallization of tourmaline cores is considered to be the result of early hydrothermal activity related to sill emplacement. Divergent fluid expulsions from sill through vertical and cleavage-parallel hydrofractures are restricted to the close vicinity of the magmatic injection. It is noteworthy that this stage of magmatic fluid expulsion might be repeated as cyclic pulses during melt crystallization. Hence, cycles of fluid expulsion may continue during the second stage

The second stage of tourmalinization (i.e., band growing, Fig. 10B) is related to homogenous fluid flow that percolated through a network made of opened cleavage planes relayed by E-W-trending extensional vertical fractures. This resulting porosity and permeability structure allowed high fluid velocities and related metasomatism. At pluton scale, one possible mechanism is homogenous flow, part of large scale convection cells triggered by the cooling of the G2 leucogranite (Norton and Knight 1977). At outcrop scale, the convergent pattern of fluid flow argues for pressure gradient driven by hydrofracturing around sill (likely more related to stage 1 of tourmilinization) and triggering sill convergent 
fluid pumping. Finally, folding (Fig. 10C) deformed and tilted the magmato-hydrothermal system.

\section{Acknowledgements}

This study has the scientific and financial support from the CNRS and BRGM through the National Research Group on Ore Deposits (GDR n²458, TRANSMET). The authors would like to thank the Editor Lars Stixrude, Jhon Ferry and the anonymous reviewers whose comments help to improve greatly this manuscript.

\section{References}

Barnes, H.L., 1997. Geochemistry of hydrothermal ore deposits, third ed. John Willey and Sons, New York.

Brenan, J., 1991. Development and maintenance of metamorphic permeability: Implication for fluid transport, in: Kerrick D-M., (Ed.), Contact metamorphism. Rev. Mineral. 26, 291-319.

Carlson, W. D., 1989. The significance of intergranular diffusion to the mechanisms and kinetics of porphyroblast crystallization. Contrib. Mineral. Petrol. 103, 1-24

Carlson, W. D., 1991. Competitive diffusion-controlled growth porphyroblasts. Mineral. Mag. 55, 317-330.

Cartwright, I., Buick, I.S., 1996. Determining the direction of contact metamorphic fluid flow: an assessment of mineralogical and stable isotope criteria. J. Metamorph. Geol. 14, 289-305. 
Cook, S.J., Bowman, J.R., Forster, C.B., 1997. Contact metamorphism surrounding the Alta stock: Finite element model simulation of heat- and O-18/O-16 mass-transport during prograde metamorphism. Am. J. Sci. 297, 1-55.

Cui, X., Nabelek, P.I., Liu, M., 2001. Controls of layered and transient permeability on fluid flow and thermal structure in contact metamorphic aureoles, with application to the Notch Peak aureole, Utah. J. Geophys. Res. 106, 6477-6491.

Ferry, J.M., Dipple, G.M., 1991. Fluid flow, mineral reactions, and metasomatism. Geology, 19, 211-214.

Ferry, J.M., 1994a. Overview of the petrologic record of fluid flow during regional metamorphism in northern New England. Am. J. Sci. 294, 905-988.

Ferry, J.M., 1994b. A historical review of metamorphic fluid flow. J. Geophys. Res. 99, 15487-15498.

Ferry, J.M., Sorensen, S.S., Rumble III, D., 1998. Structurally controlled fluid flow during contact metamorphism in the Ritter Range pendant, California, USA. Contrib. Mineral. Petr. 130, 358-378.

Ferry, J., Wing, B., Penniston-Dorland, S., Rumble, D., 2002. The direction of fluid flow during contact metamorphism of siliceous carbonate rocks: new data for the Monzoni and Predazzo aureoles, northern Italy, and a global review. Contrib. Mineral. Petr. 142, 679-699.

Garside., J., Janssen-van Rosmalen, R., Bennema, P., 1975. Verification of crystal growth rate equation. J. Crystal Growth 29, 353-366. 
Gerdes, M.L., Baumgartner, L.P., Person, M., 1998. Convective fluid flow through heterogeneous country rocks during contact metamorphism J. Geophys. Res. 103, B10, 23983-24003.

Gilmer, G.H., Chez, R., Cabrera N., 1971. An analysis of combined surface and volume diffusion processes in crystal growth. J. Crystal Growth 8, 79-93.

Gloaguen, E., Chauvet, A., Branquet, Y., Bouchot, V., Barbanson, L., Vigneresse, J-L, 2008 Mechanical instabilities, strain localization and vein formation on granite roof: The example of the hercynian Boborás granite (Galicia, Spain), submitted to Journal of Structural Geology.

Gloaguen, E., Chauvet, A., Branquet, Y., Gerbeaud, O., Ramboz, C., Bouchot, V., Lerouge, C., Monié, P., Cathelineau, M., Boiron, M.C., Marignac, C., Pourraz, N., Fourcade, S., Ruffet, G., Iglesias Ponce de León, M., 2003. Relations between Au / Sn-W mineralizations and late hercynian granite: Preliminary results from the Schistose Domain of Galicia-Trás-os-Montes Zone, Spain. $7^{\text {th }}$ biennal SGA meeting - Mineral Exploration and Sustainable Development, Athens, Greece, 1, 271-274.

Gloaguen, E., Chauvet, A., Branquet, Y., Barbanson, L., Bouchot, V., 2004. The magmatichydrothermal transition within intrusion-related gold and tin-tungsten deposits: Examples of late-hercynian Boborás and Beariz granites (Galicia, NW Spain). 20ème Réunion des Sciences de la Terre, 20-25 Septembre 2004, Strasbourg, France, Résumé n RSTGV-A-00241.

Gloaguen, E., 2006. Apports d'une étude intégrée sur les relations entre granites et minéralisations filoniennes ( $\mathrm{Au}$ et $\mathrm{Sn}-\mathrm{W}$ ) en contexte tardiorogénique (Chaîne 
Hercynienne, Galice centrale, Espagne). Unpublished PhD Thesis. Université d'Orléans. http://tel.archives-ouvertes.fr

Gonzalez Cuadra, P., 1996. Analisis petrostructural des granite de Beariz (NO de Ourense, Galicia). Unpublished Thesis. Oviedo University, 49 pp.

Gratier, J.P., Gueydan, F., 2007. Deformation in the Presence of Fluids and Mineral Reactions. Effect of Fracturing and Fluid-Rock Interaction on Seismic Cycles, in: Handy, M.R., Hirth G., Hovius N. (Eds.), Tectonic Faults - Agents of Change on a Dynamic Earth. MIT Press, pp. 319-356.

Hanson, R.B., Sorensen, S.S., Barton, M.D., Fiske, R.S., 1993. Long-Term Evolution of Fluid-Rock Interactions in Magmatic Arcs: Evidence from the Ritter Range Pendant, Sierra Nevada, California, and Numerical Modeling. J. Petrol. 34, 23-62.

Hawthorne, F.C., Henry, D.J., 1999. Classification of the minerals of the tourmaline group. Eur. J. Mineral. 11, 201-215.

Henry, D.J., Guidotti, C.V., 1985. Tourmaline as a petrogenetic indicator mineral: an example from the staurolite-grade metapelites of NW Maine. Am. Mineral. 70, 1-15.

Ildefonse, J.P., Gabis, V., 1976. Experimental study of silica diffusion during metasomatic reaction in the presence of water at $550^{\circ} \mathrm{C}$ and 1000 bars. Geochim. Cosmochim. Acta, 40, 297-303.

Ingebritsen, S.E., Manning C.E., 1999. Geologic implications of a permeability-depth curve for continental crust. Geology 27, 1107-1110.

Labotka, T.C., 1991. Chemical and physical properties of fluids, in: Kerrick D-M., (Ed.), Contact metamorphism. Rev. Mineral. 26, 43-104. 
London, D., Manning, D.A.C., 1995. Chemical variation and significance of tourmaline from southwest England. Econ. Geol. 90, 495-519.

Manning, C.E., Ingebritsen, S.E., 1999. Permeability of the continental crust: implications of geothermal data and metamorphic systems. Rev. Geophys. 37, 127-150.

Monier, G., Robert, J.L., 1986. Muscovite solid-solutions in the system $\mathrm{K}_{2} \mathrm{O}-\mathrm{MgO}-\mathrm{FeO}-$ $\mathrm{Al}_{2} \mathrm{O}_{3}-\mathrm{SiO}_{2}-\mathrm{H}_{2} \mathrm{O}-$ An experimental study at $2 \mathrm{kBar} \mathrm{P} \mathrm{H}_{2} \mathrm{O}$ and comparison with natural Li-free white micas. Mineral. Mag. 50, 257-266.

Norton, D., Knight, J., 1977. Transport phenomena in hydrothermal systems: cooling plutons. Am. J. Sci. 277, 937-981.

Oliver, N.H.S., McLellan, J.G., Hobbs, B.E., Cleverley, J.S., Ord, A., Feltrin, L., 2006. Numerical models of extensional deformation, heat transfer, and fluid flow across basement-cover interfaces during basin-related mineralization. Econ. Geol. 101, 1-31.

Prieto, M., Paniagua, A., Marcos, C., 1996. Formation of primary inclusions under influence of hydrodynamic environment. Eur. J. Mineral. 8, 987-996.

Rossetti, F., Tecce, F., Billi, A., Brilli, M., 2007. Patterns of fluid flow in the contact aureole of the Late Miocene Monte Capanne pluton (Elba Island, Italy): the role of structures and rheology. Contrib. Mineral. Petr. 153, 743-760.

Sizaret, S., Gloaguen, E., Barbanson, L., Chauvet, A., Branquet, Y., Swennen, R., 2004. Cristallisation et circulations fluides, apports de la modélisation et applications à l'estimation des paléo-vitesses. 20ème Réunion des Sciences de la Terre, 20-25 Septembre 2004, Strasbourg, France, Résumé n RSTGV-A-00377. 
Sizaret, S., Fedioun, I., Barbanson, L., Chen, Y., 2006a. Crystallisation in flow Part II: Modelling crystal growth kinetics controlled by boundary layer thickness. Geophys. J. Int. $167,1027-1034$.

Sizaret, S., Chen, Y., Barbanson, L., Camps, P., Henry, B., Marcoux, E., 2006b. Crystallisation in flow Part I: Paleo-circulation track by texture analysis and magnetic fabrics. Geophys. J. Int. 167, 605-612.

Skelton, A.D.L., 1997. The effect of metamorphic fluid flow on the nucleation and growth of garnets from Troms, North Norway. J. metamorphic Geol. 15, 85-92.

Tenthorey, E., Fitz Gerald, J.D., 2006. Feedbacks between deformation, hydrothermal reaction and permeability evolution in the crust: Experimental insights. Earth Planet. Sc. Lett. 247, 117-129.

Walther, J.V., Orville, P.M., 1982. Volatile production and transport in regional metamorphism. Contrib. Mineral. Petrol. 79, 252-257.

Wing, B.A., Ferry J.M. 2007. Magnitude and geometry of reactive fluid flow from direct inversion of spatial patterns of geochemical alteration. Am. J. Sci. 307, 793-832. 


\section{Figure captions}

Fig. 1: Numerical modeling, (A) Boundary conditions used for modeling crystal growth in a fluid flow. The symmetry condition is used far from the crystal when the flow is parallel to the boundary. The flux integrated on this boundary is zero. Along the crystal wall the dimensionless concentration is $\chi_{w}=0$ and the velocity is $V_{w}=0$; at infinity in the upstream position $\chi_{\infty}=1$ and $V_{\infty}$ is assigned different values in the simulations. (B) Variation of the dimensionless concentration calculated on a regular mesh, (C) flux of the dimensionless concentration along the different crystal faces. Fw(A) and Fw(D) are the minimum wall fluxes respectively of the upstream and downstream faces, (D) present the concentration profile parallel to flow velocity and passing through the crystal. The local diffusion thickness is calculated using the concentration gradient at the crystal solution interface. The flux ratio $\mathrm{R}$ is calculated for $v_{25^{\circ} \mathrm{C}}, \mathrm{D}_{25^{\circ} \mathrm{C}}$ and $V_{\infty}=10^{-4} \mathrm{~m} / \mathrm{s}$.

Fig. 2: Curves showing the variation of (A) flux ratio and (B) diffusion thickness with the flow velocity. Grey curves are calculated at $25^{\circ} \mathrm{C}$ and black at $350^{\circ} \mathrm{C}$. Diamonds represent the ratio of average flux on the upstream and downstream faces; squares are the ratio of the minimum fluxes.

Fig. 3: Geological map (Gloaguen, 2006, modified from Gonzales Cuadra, 1996). (A) Location of the studied area; (B) geological map of the Beariz plutonic complex. Tourmalinite halos are related to the G2 leucogranite, emplaced during a broad N-S stretching (X) associated with a E-W shortening 
Fig. 4: Mina Soriana outcrop. (A) The deformed leucogranite sill, (B) tourmalinite cut by veinlets, (C) quartz tourmaline veins, (D) metasomatic tourmalinite associated with sill (E and $\mathrm{F}$ indicate the position of the thin sections $\mathrm{E}$ and $\mathrm{F}$ ), (E) tourmaline oriented with $\mathrm{N}-\mathrm{S}<\mathrm{C}>$ axis, (F) vertical E-W thin section showing (0001) plan normal to trigonal $<_{\mathrm{C}}>$ axis. In this section the anisotropic growth bands show a symmetry breakdown due to metasomatic flow.

Fig. 5: Marcofan outcrop. (A) and (B) Pegmatite sill associated with tourmalinite halo (C and D indicate the position of the thin section c and D), (C) vertical section showing the N-S orientation of the tourmaline $<_{\mathrm{C}}>$ axis, (D) vertical E-W thin section showing (0001) plan normal to trigonal $<_{\mathrm{C}}>$ axis. In this section the anisotropic growth bands show a symmetry breakdown due to metasomatic fluid flow. Signification de C et D dans la figure B.

Fig. 6: Geochemistry of tourmalines from the Beariz G2 leucogranite complex. Electon microprobe analyses were performed at the ISTO-BRGM laboratory using a Cameca SX 50 (15 kV, $15 \mathrm{nA}$, counting time: $10 \mathrm{~s}$ ). $\mathrm{X}$ vacant site diagram (A): $\mathrm{Al}_{50} \mathrm{Fe}_{50}-\mathrm{Al}-\mathrm{Al}_{50} \mathrm{Mg}_{50}$ diagram relating tourmaline composition to crystallization environment (Henry and Guidotti, 1985). (B): Fe vs. Mg diagram showing substitutions in tourmalines (London and Manning, 1995).

Fig. 7: Method for growth band measurements. (A) Example of measurement on a tourmaline section showing variable growth thickness; (B) relative distribution of $d_{\text {max }}$, $d_{\text {int }}$ and $d_{\text {min }}$ if the crystal is influenced by flow. Dans la figure, (ellipsoïde) mettre peut être des doubles flèches pour désigner sans ambiguité dmin, dmax et dint ou un grospoint à l'origine. 
Fig. 8: Direction of the normalized growth band thicknesses measured on tourmaline of Mina Soriana; (A,D) maximum and (B,C) minimum directions give average upstream and downstream direction. (A, B) and (C, D) are measures on tourmalines respectively located above and below the leucogranite sills. Blacks arc give the $\alpha_{95}$ interval of confidence.

Fig. 9: Direction of the normalized growth band thicknesses measured on tourmaline of Marcofan; (A,C) maximum and (B,D) minimum directions give average upstream and downstream direction. (A, B) and (C, D) are measures on tourmalines respectively located westward and eastward from the pegmatite sill.

Fig. 10: Tectono-hydrodynamic model of massive tourmalinization around the Beariz granite. See explanation in text. 
(A)

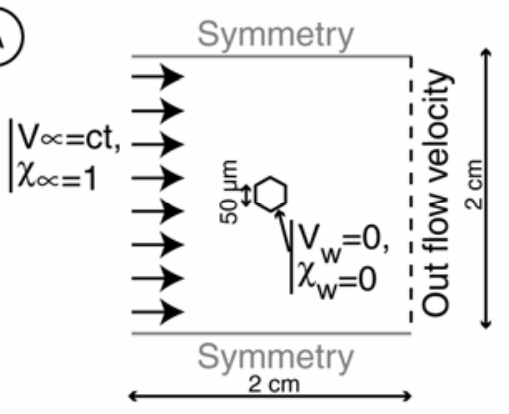

(C)

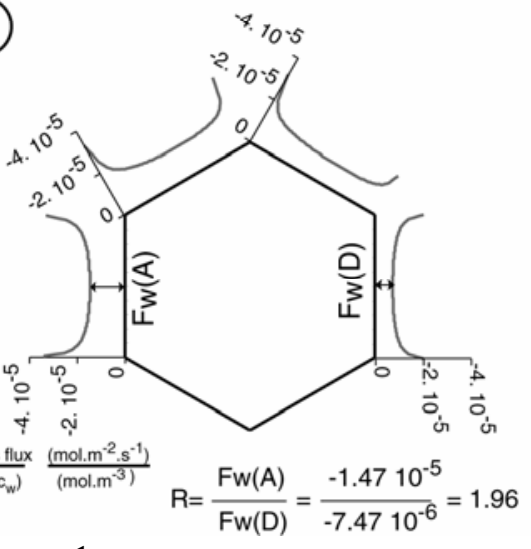

Figure 1

(A)

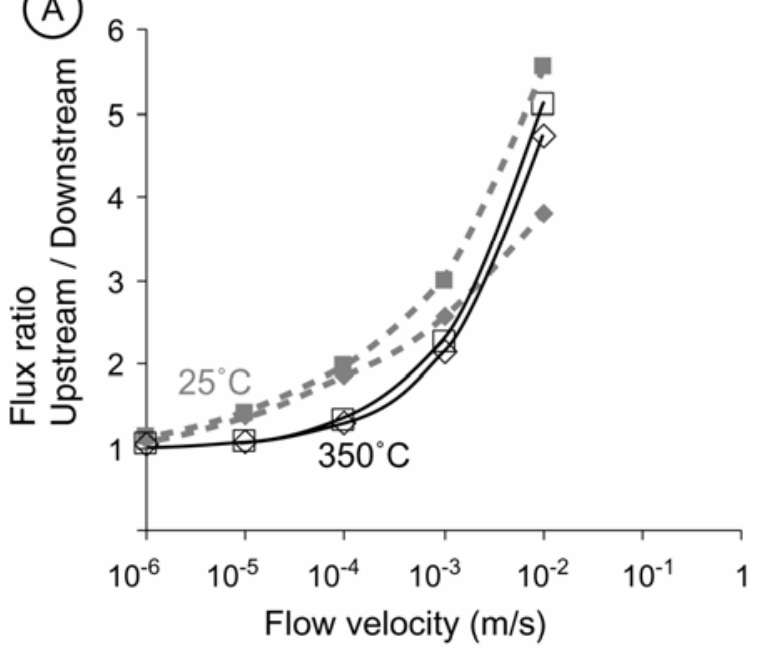

$\diamond \diamond$ Ratio of the average fluxes

$\square \backsim$ Ratio of minimum fluxes $\frac{\text { Mass flux }}{\left(c_{\infty}-c_{w}\right)} \frac{\left(m_{0} m^{-2} \cdot s^{-1}\right)}{\left(m o l . m^{-3}\right)} \quad R=\frac{F w(A)}{F w(D)}=\frac{-1.4710^{-5}}{-7.4710^{-6}}=1.96$
(B)

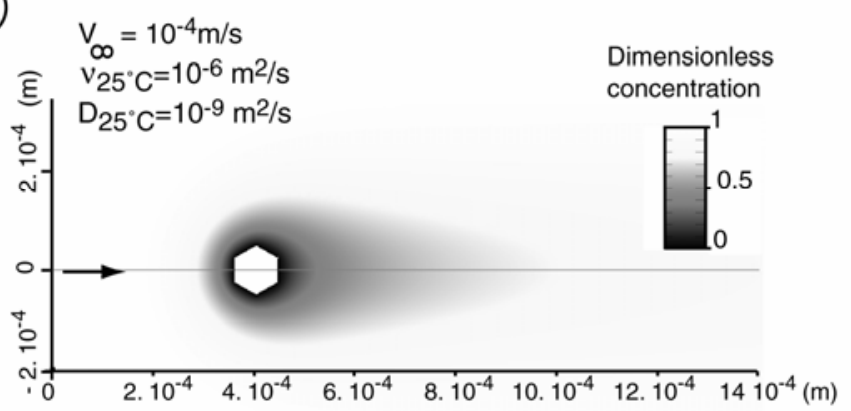

(D)

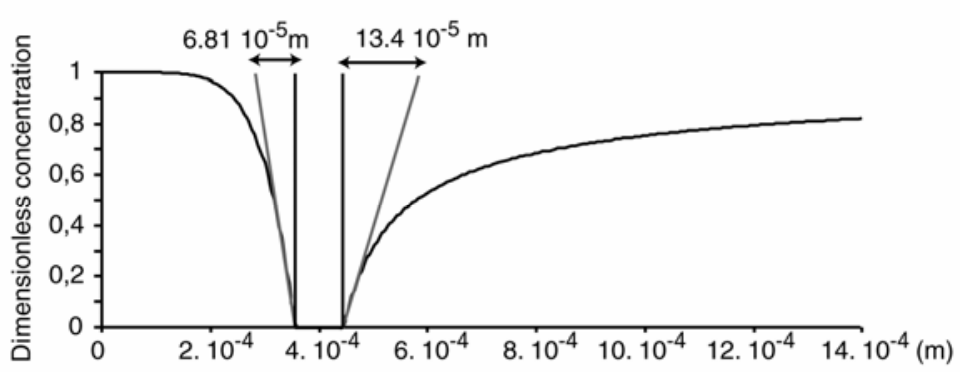


Figure

2

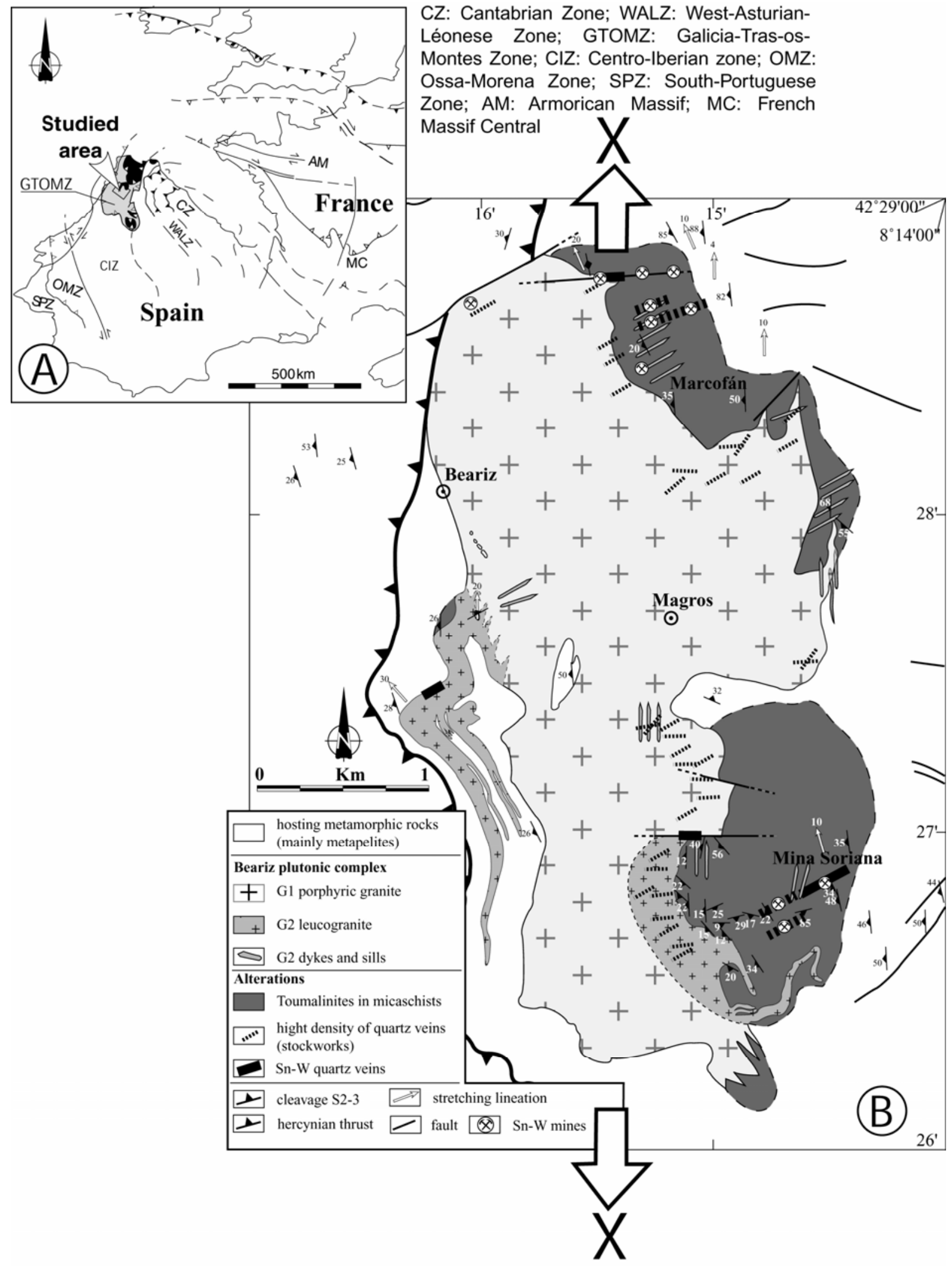

Figure 3 

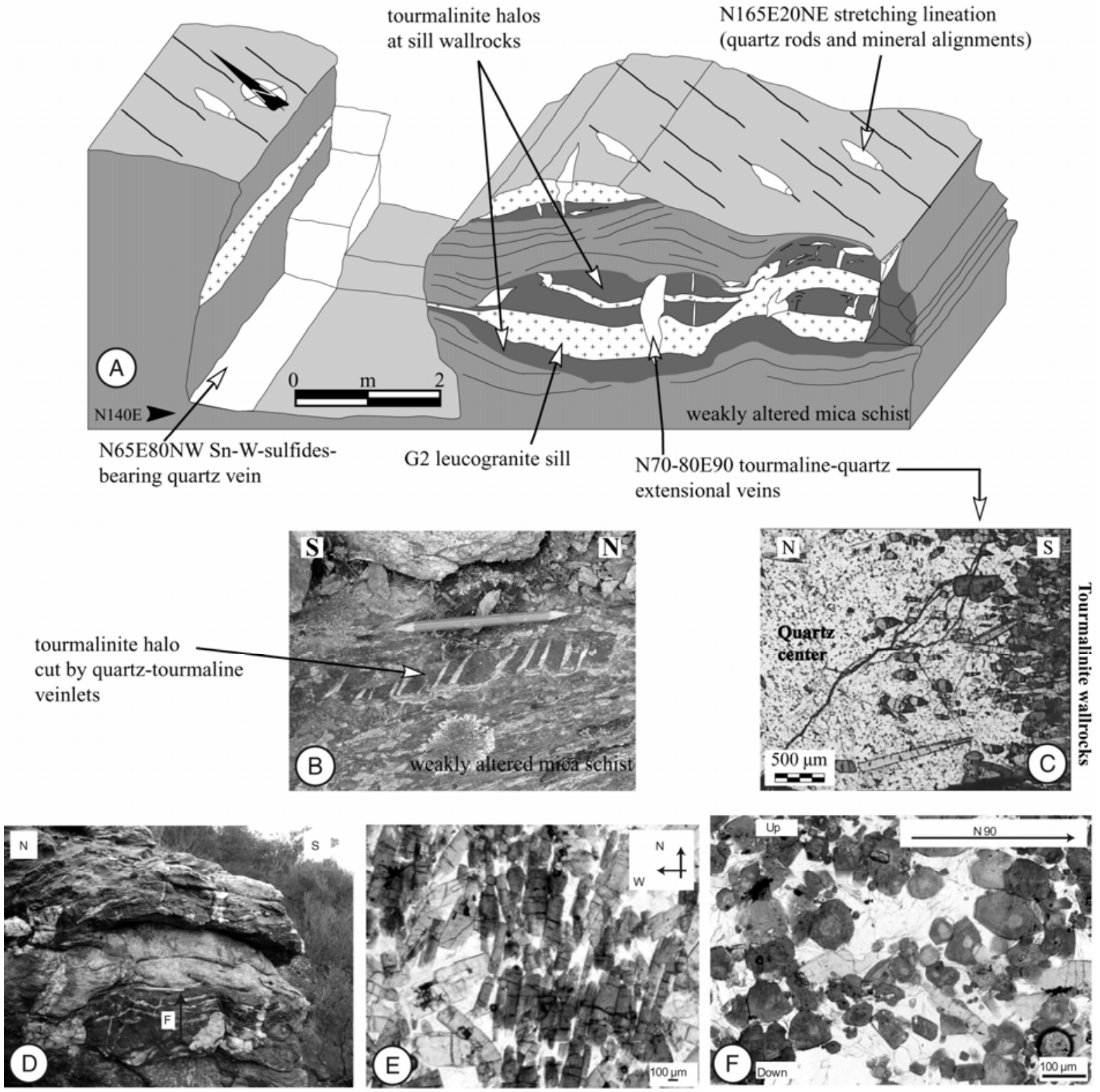

Figure 4 


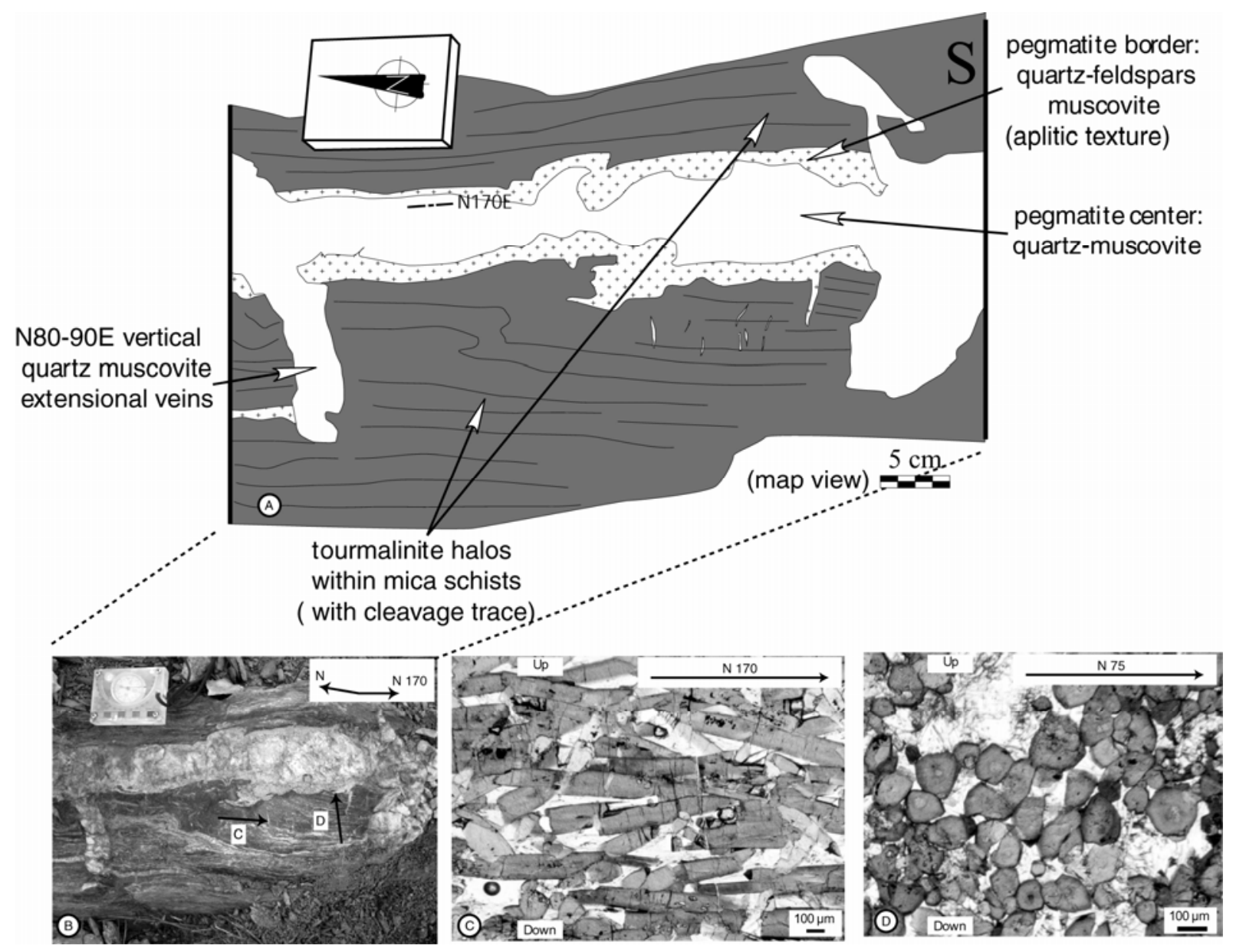

Figure 5 

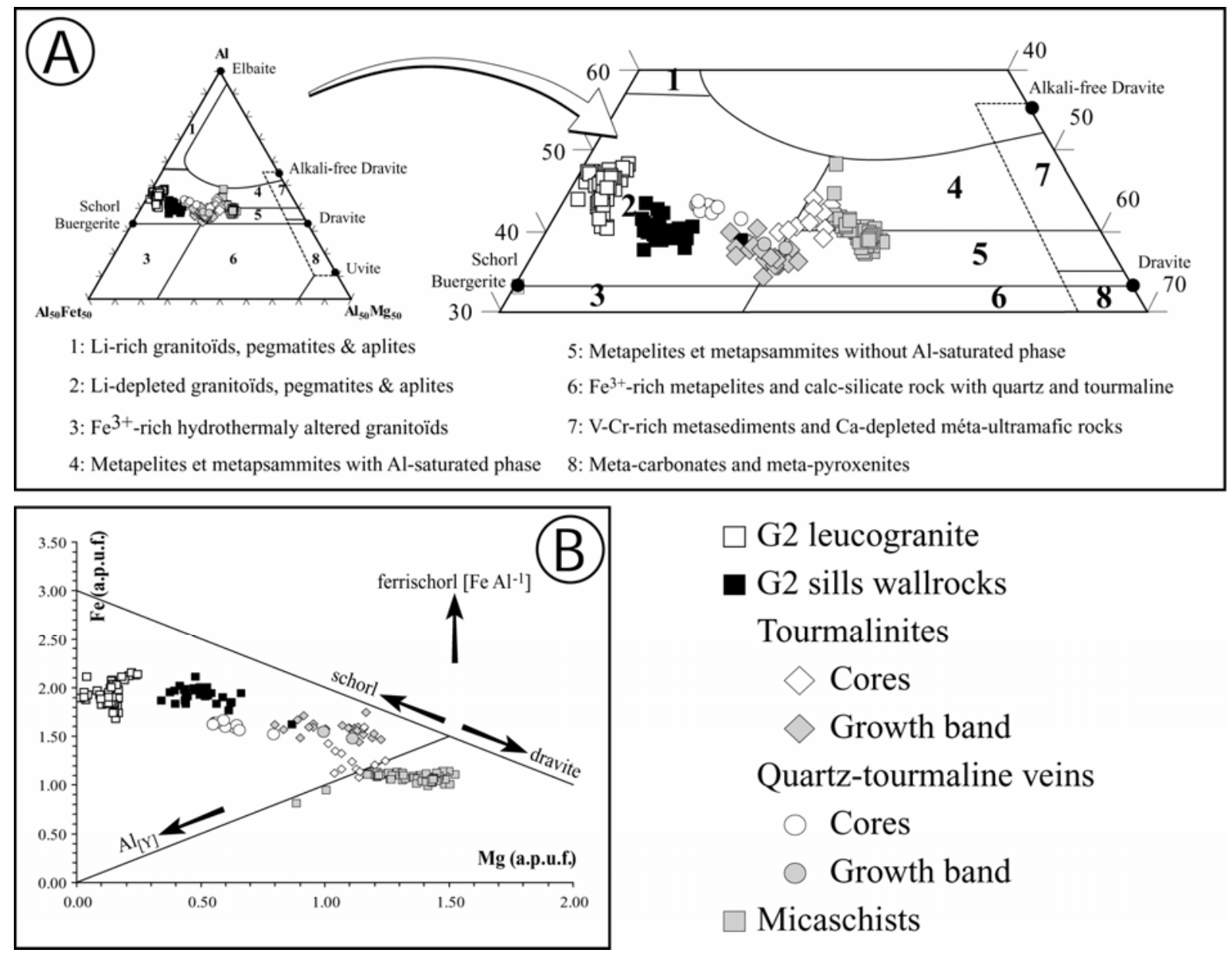

$\square$ G2 leucogranite

- G2 sills wallrocks

Tourmalinites

\section{Cores}

Growth band

Quartz-tourmaline veins

Cores

Growth band

Figure 6

\section{Micaschists}

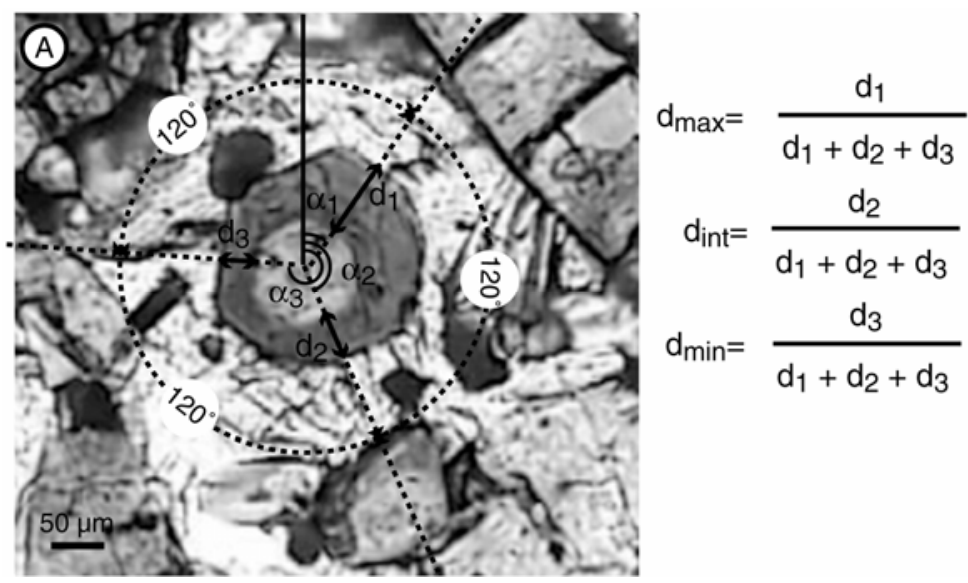

(B)

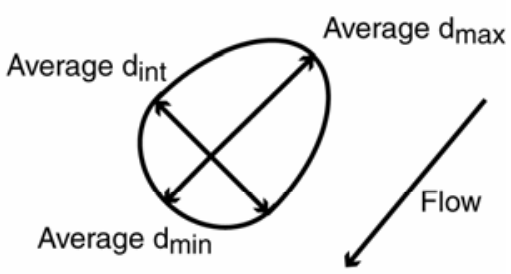

Figure 7 
(A)

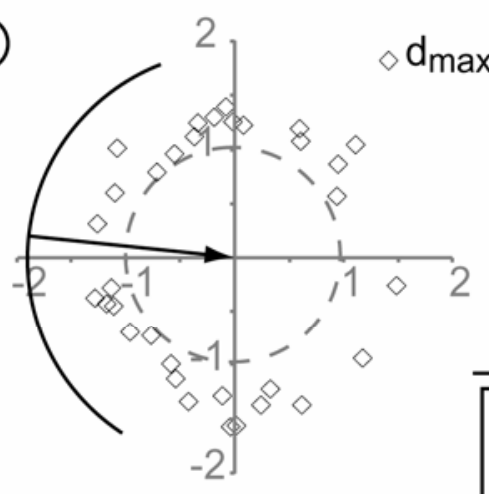

(D)

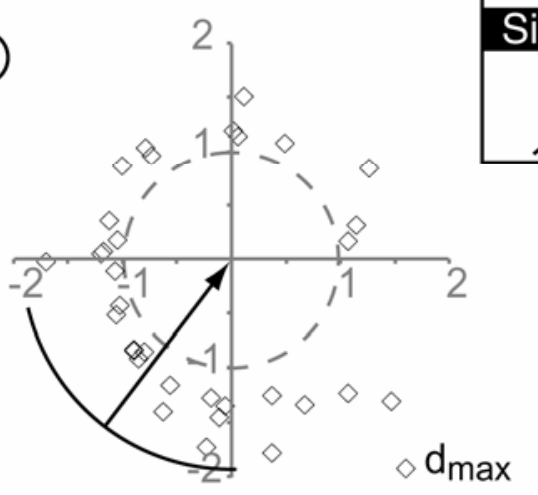

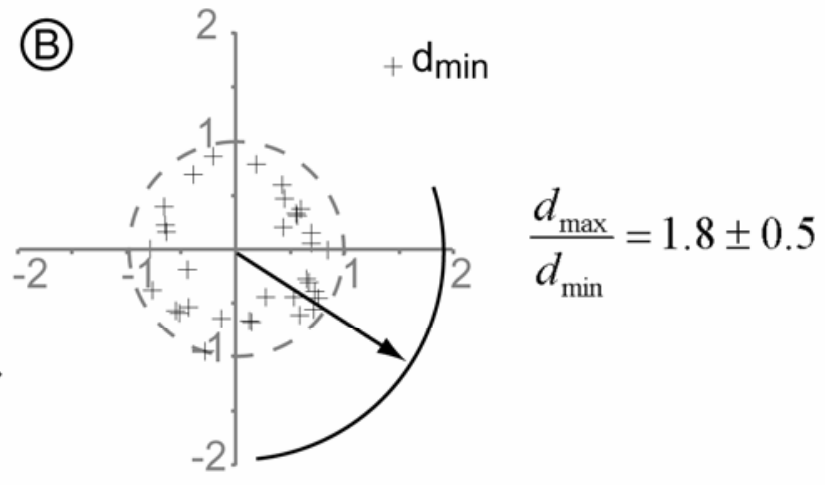

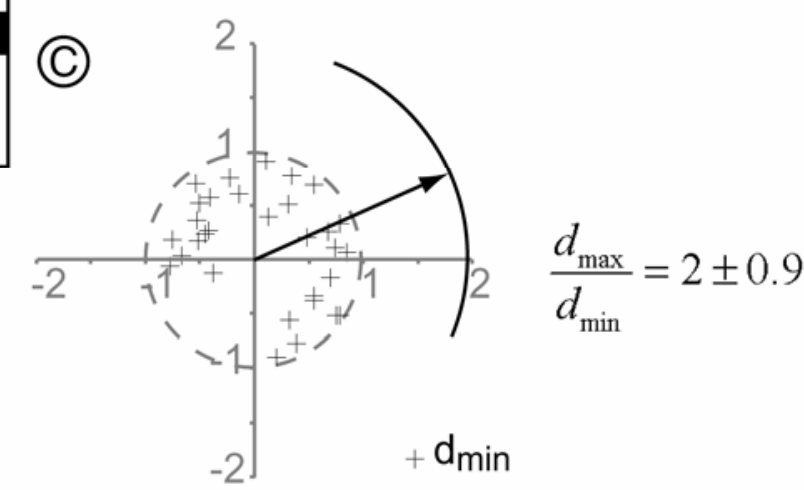

Sill

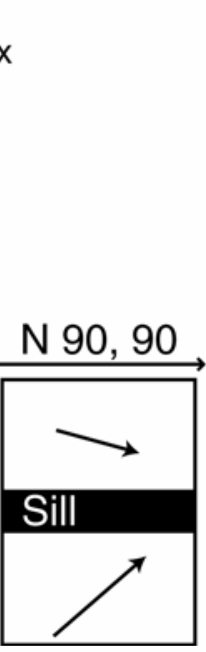

(B)

$-2$

Figure 8

(A)

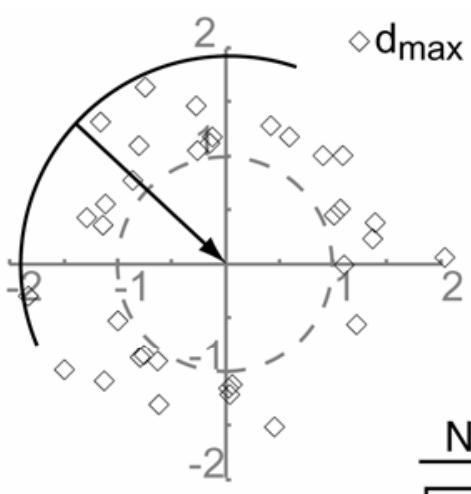

(C)

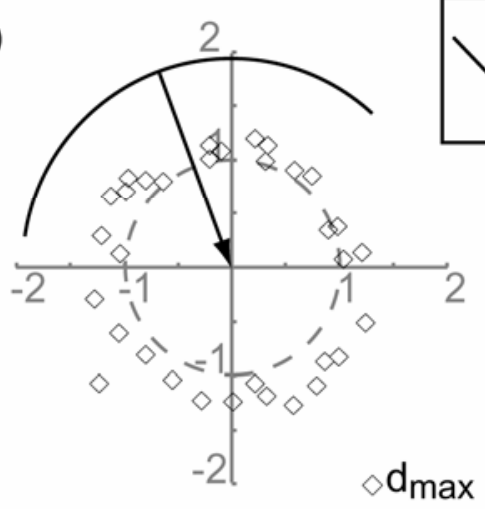



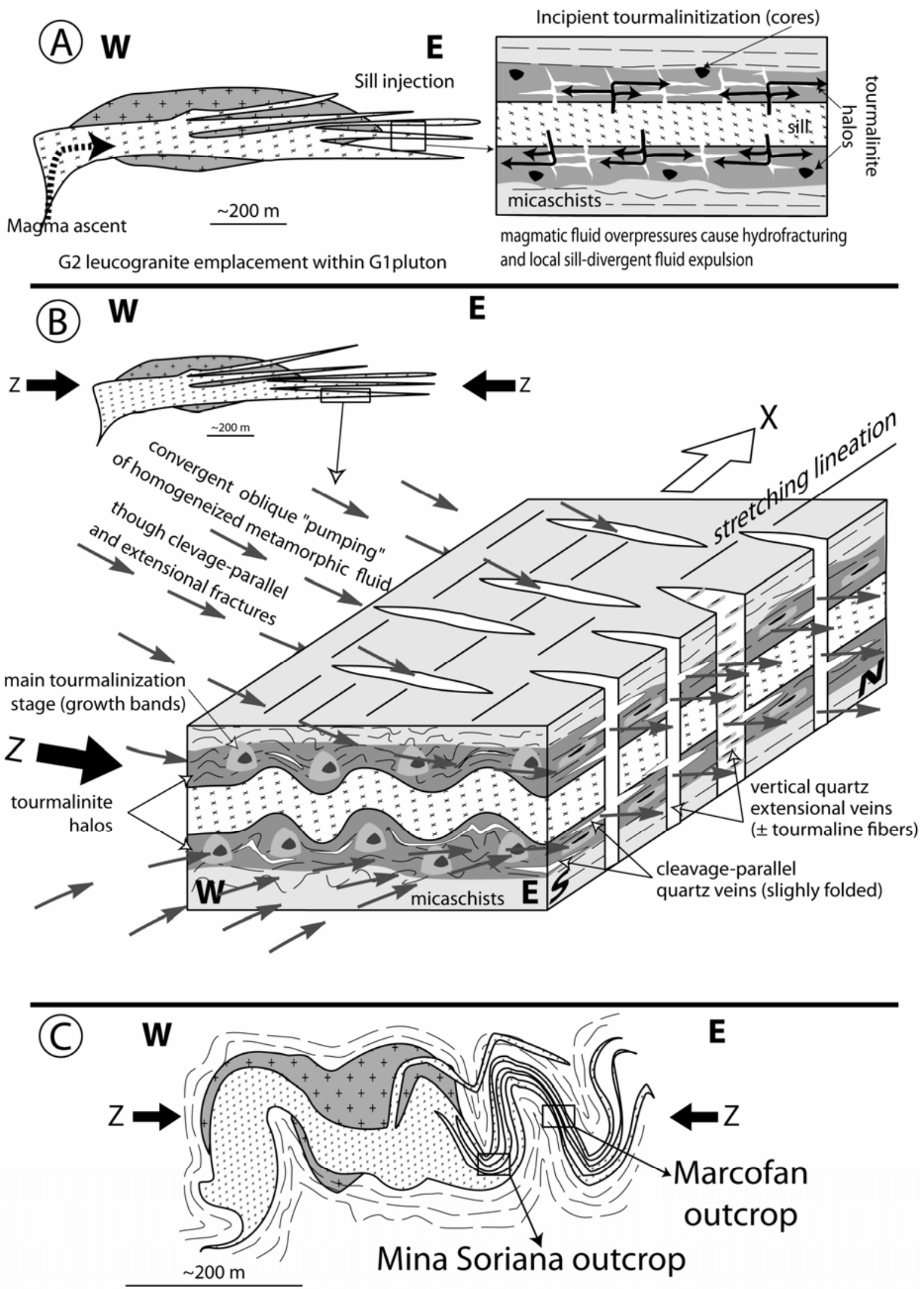

Figure 10 
